\title{
Drivers and barriers of reverse logistics practices: A study of large grocery retailers in South Africa
}

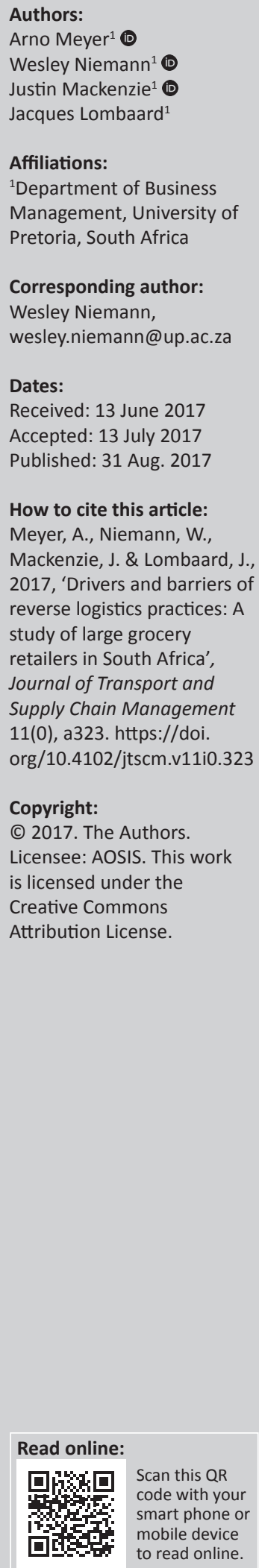

Background: Reverse logistics (RL) practices have previously been viewed as a cost drain, but have received greater attention from practitioners because of increasing competition and dwindling margins.

Purpose: The purpose of this generic qualitative study was to uncover the main internal and external drivers and barriers of RL within major South African grocery retailers.

Method: Eleven face-to-face, semi-structured interviews and one telephonic interview were conducted with participants from four large grocery retailers.

Findings: Optimising profitability and cost reduction goals are the identified internal drivers, whereas the main external driver was to reduce the organisations' environmental impact. A lack of information systems - such as enterprise resource planning systems or warehouse management system software - and infrastructure were revealed as the main internal barriers for organisations' RL practices, whereas supplier non-compliance and transportation inefficiencies were the main external barriers exposed.

Managerial implications: In order to optimise the efficiency of the reverse flow, managers are recommended to devote more capital to RL infrastructure, develop policies to manage supplier behaviour, focus on RL as a revenue generating stream as well as implement information systems to manage the entire reverse flow.

Conclusion: All participating grocery retailers follow similar RL processes. Growth in RL practices as well as infrastructure to perform those practices is a future priority for all the reviewed grocery retailers. RL is no longer only a key cost driver, but also provides organisations with many additional opportunities.

\section{Introduction and problem statement}

The Council of Supply Chain Management Professionals (CSCMP 2013) defines reverse logistics (RL) as:

a specialist segment of logistics focussing on the movement and management of products and resources after the sale and after delivery to the customer and includes product returns for repair and/or credit. (p. 168)

RL is an old-age practice dating back to the roots of American Civil War, but only started receiving more attention in the last few decades (Cannella, Bruccoleri \& Framinan 2016:36; Rubio, Chamorro \& Miranda 2008:1099; Rutner, Aviles \& Cox 2012:95).

In the past 200 years, the remarkable progress of industrialisation and economic development has accelerated the global interchange of people, goods and information, making it very difficult for self-recovery (Subramanian et al. 2014:235; Ye et al. 2013:132). Natural resources used for the inputs of consumer goods are becoming scarce and more costly, while at the same time consumers are becoming more environmentally conscious, thus emphasising the importance of RL practices as a means to achieving price competitiveness in the grocery retail industry (Lamsali 2013:1; Tejwani \& Sethi 2012:16).

According to Dobbs et al. (2011) and Schulte (2013:44), the world's population has multiplied sevenfold, to approximately 7 billion people in two centuries, with an estimated 3 billion more people entering the global middle class by 2030 (McKinsey \& Company 2011; Schulte 2013:44). The resources of two centuries ago are no longer an inexhaustible source of wealth, especially with the global rise of per capita resources (Dobbs et al. 2011; Schulte 2013:44). Conducting RL practices will enable organisations to recover as much value from those resources as possible, 
minimising global resource scarcity (Mafakheri \& Nasiri 2013:187; Ramírez 2012:1137).

In 2015, South Africa had a population growth rate of $1.6 \%$ (World Bank 2016). South Africa's growing population effects the amount of products that are consumed; thus, conducting activities such as direct reuse, product recovery and waste management will allow the organisation to recapture the value of the products and achieve long-term sustainability in resources and profitability (Chan, Chan \& Jain 2012:1319; Thamsatitdej et al. 2015:1588).

Most of the prior RL research focussed on drivers and barriers in developed countries and relatively little attention has been devoted to developing countries, such as South Africa (Abdulrahman, Gunasekaran \& Subramanian 2014:460; Bouzon, Govindan \& Rodriguez 2015:27; Subramanian et al. 2014:235). Studies in the South African context include a framework for prioritising practices to overcome cost-related problems in RL (Badenhorst 2013b:1-10), a study prioritising the implementation of practices to overcome operational barriers in RL (Badenhorst 2016:1-12) and supply chain integration in the product returns process (Mostert, Niemann \& Kotzé 2017:1-18). This study responds to a call from Badenhorst (2016:10) for a qualitative study that explores the barriers and practices of RL in South Africa.

RL has been previously viewed as a cost-draining activity or a non-value adding aspect of the supply chain; however, RL practices can positively impact financial performance by recovering the value of products (Peretti et al. 2015:266; Ramírez 2012:1137; Vlachos 2016:1). The main purpose of this qualitative study was to identify the internal and external drivers and barriers of RL, as experienced by the large South African grocery retailers. Removing these barriers may allow the organisation to enhance profitability, sustainability and develop a competitive advantage from the practices (Chan et al. 2012:1319; Gold, Hahn \& Seuring 2013:784; Nikolaou, Evangelinos \& Allan 2013:173).

The study endeavours to answer the following research questions:

- What RL practices do South African grocery retailers currently implement?

- What are the key internal and external drivers for RL practices in the South African retail grocery industry?

- What are the key internal and external barriers to RL practices in the South African retail grocery industry?

- What is the nature of the competitive advantage that results from RL practices in the South African retail grocery industry?

The results of the research indicate major barriers that can be reduced, which will likely increase the efficiency of the organisation's RL operation and lead to cost-saving opportunities. According to Prakash and Barua (2015:599), there is a great need for solutions that overcome the barriers of RL; therefore, this study proposes solutions to combatting barriers within RL.
Managers benefit from those solutions, as they have the opportunity to reduce the RL barriers, thereby increasing the efficiency of the entire RL operation. Providing clarity on the main benefits of RL practices enables management to capitalise and not undervalue the importance of an RL operation.

\section{Literature review South African grocery retail industry}

In 2014, food and grocery sales topped R514 million, accounting for $58.4 \%$ of total retail sales and contributing $5.7 \%$ to the gross domestic product of South Africa (BMI Research 2016:14; PWC 2016). There are currently four large grocery retailers in the South African grocery retail industry; however, aggressive competition requires those organisations to prioritise cost control and efficiencies in order to remain price competitive (BMI Research 2016:36; PWC 2016). RL practices are important to the industry as they enable the organisation to recover costs and generate revenue through product recovery and backhauling, as well as maintain the safety of consumers through proper product disposal, thus protecting the organisation's image (Larsen \& Jacobsen 2016:787; Marchi, Maria \& Micelli 2013:70). Environmentally, RL practices also enable greater resource sustainability through product recovery, thus reducing the effects of a consumerism ideology in the grocery retail industry (Diabat \& Govindan 2011:659; Zhu \& Geng 2013:6).

\section{Reverse logistics practices}

RL has been defined in numerous ways by various authors. RL has evolved from a relatively simple concept into a much more complex phenomenon as indicated in Table 1.

For the purpose of this research study, the definition proposed by Arrieta (2015:9) is adopted. This is the most appropriate definition, as it encompasses all of the RL practices and is purposely extensive to include a diverse array of services that grocery retailers are likely to undertake.

TABLE 1: Definitions of reverse logistics.

\begin{tabular}{ll}
\hline Author & Definition \\
\hline $\begin{array}{l}\text { Pohlen and Farris } \\
\text { (1992:35) }\end{array}$ & $\begin{array}{l}\text { The movement of goods from a consumer towards a } \\
\text { producer in a channel of distribution }\end{array}$ \\
Banks (2002:1) & $\begin{array}{l}\text { The timely and accurate movement of service-related and } \\
\text { non-service-related materials from a user back through the } \\
\text { supply chain to the appropriate activity }\end{array}$ \\
$\begin{array}{l}\text { Sharma et al. } \\
\text { (2011:101) }\end{array}$ & $\begin{array}{l}\text { All the operations related to the reuse of used products, } \\
\text { excess inventory of products and materials including } \\
\text { collection, disassembly and processing of used products, } \\
\text { parts and/or materials }\end{array}$ \\
CSCMP (2013:168) & $\begin{array}{l}\text { A specialist segment of logistics focusing on the movement } \\
\text { and management of products and resources after the sale } \\
\text { and after delivery to the customer and includes product } \\
\text { returns for repair and/or credit }\end{array}$ \\
Arrieta (2015:9) & $\begin{array}{l}\text { The process of moving goods from the point of usage or } \\
\text { consumption for the purpose of recapturing value, or proper } \\
\text { disposal; including activities such as remanufacturing and } \\
\text { refurbishing, processing of returned damaged products, } \\
\text { seasonal inventory, recalls (return implemented because of } \\
\text { safety or quality reasons), recycling programmes, hazardous } \\
\text { material programmes, obsolete equipment disposition and } \\
\text { asset recovery }\end{array}$ \\
\hline
\end{tabular}

Note: Please see the full reference list of the article, Meyer, A., Niemann, W., Mackenzie, J. \& Lombaard, J., 2017, 'Drivers and barriers of reverse logistics practices: A study of large grocery retailers in South Africa', Journal of Transport and Supply Chain Management 11(0), a323. https://doi.org/10.4102/jtscm.v11i0.323, for more information. 
Figure 1 shows the upstream flow of goods within a supply chain that involves a number of key processes, namely, product return, direct reuse, product recovery management and waste management.

\section{Product returns}

Returns can enter the supply chain from various entities, namely manufacturers, distributors or customers (Gilanli, Altug \& Oguzhan 2012:393; Lambert, Riopel \& Abdul-Kader 2011:562). Manufacturer returns include cases where products have failed quality checks and need to be reworked to a specific standard, whereas distribution returns normally take the form of product recalls, where products are recalled because of health and safety reasons (Carrasco-Gallego, Ponce-Cueto \& Dekker 2012:5582; Chopra et al. 2012; Zhao, Li \& Flynn 2013:115). Customers, by means of reimbursement guarantees, warranties or full exchange discounts, initiate customer returns (Bernon, Rossi \& Cullen 2011:486; Holweg, Teller \& Kotzab 2016:639).

Product returns make up the genesis of the RL process, which then form a number of sequential processes (Bernon et al. 2011:491; Silva et al. 2013:379). A request for return usually initiates the RL process, where one of the various entities communicates with a supplier or distribution centre (DC) to return the product (Bernon et al. 2011:491; Tan \& Chanchaichujit 2016:11). A gatekeeping process is then undertaken, where the organisation will authorise a return, as well as the sharing of information regarding that return (Badenhorst 2016:3; Tan \& Chanchaichujit 2016:11).

Once authorisation is provided, the returned products are delivered to the applicable facility for inspection, sorting and disposition (Lambert et al. 2011:561; Rogers, Melamed \& Lembke 2012:108). More detailed inspections of the product will then take place to evaluate its quality, and a sortation process will categorise those products for use in further processes (Agrawal, Singh \& Murtaza 2015:77; Rogers et al. 2012:108). The products then follow a disposition strategy where they are reused, recovered or wasted (Akdoğan \& Coşkun 2012:1642; Hazen, Hall \& Hanna 2012:248).

\section{Direct reuse}

Direct reuse simply means that products can be resold in their current condition or reused for a purpose similar to the one it was designed for (Hazen, Cegielski \& Hanna 2011:375; Hazen et al. 2012:248). Detailed inspections and manipulations are conducted in order to evaluate the functioning or quality of the products under consideration (Hazen et al. 2011:375, 2012:248). Products will be reused, repackaged or sold off to the second-hand market within this process (Akdoğan \& Coşkun 2012:1643; Lambert et al. 2011:562).

Repackaging normally takes place where the original packaging gets damaged and is then restored or reworked, in order for it to conform to a specific standard, thus maintaining the organisation, as well as the products image (Arrieta 2015:16; Holweg et al. 2016:650). Products that have been damaged at a retail or DC level may also be reused in other areas of the organisation, for example, an in-store bakery (Holweg et al. 2016:651). It is also possible to sell the returned items to the second-hand market at a discounted rate, which may include sales to staff, pig farmers or other third parties (Badenhorst 2016:3; Silva et al. 2013:379). When none of these actions are undertaken, the product recovery process will then take place.

\section{Product recovery management}

The recovery process recovers any potential lost cost by recovering as much value as possible from the returned products (Hazen et al. 2012:249; Lambert et al. 2011:561). Products can be recycled, which entails recovering or

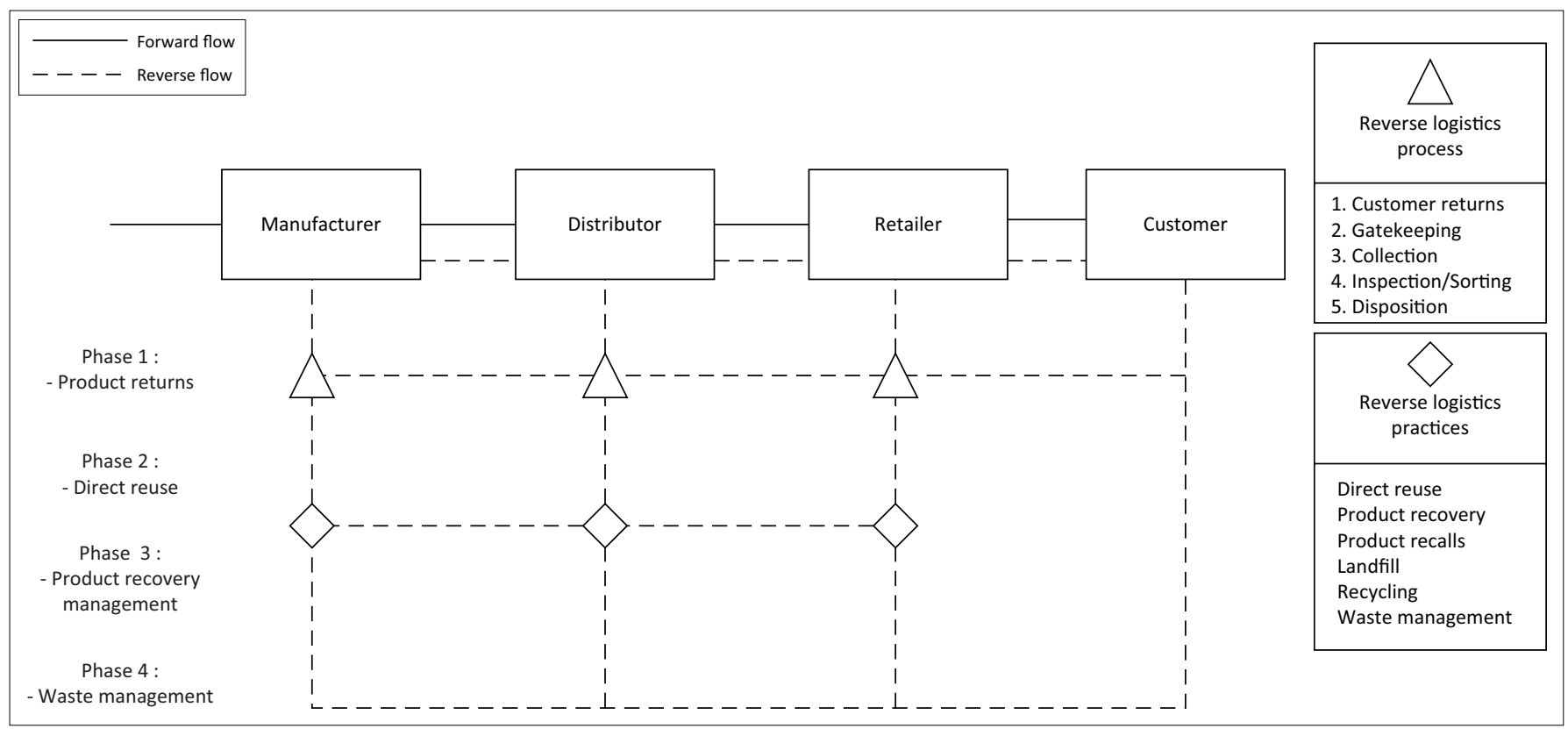

FIGURE 1: Reverse logistics practices. 
extracting recyclable materials for reuse at a later stage (Akdoğan \& Coşkun 2012:1643; Chan et al. 2012:1324). Products can also be reworked, which entails repackaging or refurbishing items into saleable batch or pallet sizes within the DC (Arrieta 2015:13; Dat et al. 2012:6381). Products could also be repaired or remanufactured to recover value; however, these two functions will not be applicable for this study because of the nature of the products and organisations that are going to be investigated (Chan et al. 2012:1324; Lambert et al. 2011:562). If value recovery is not a viable option, the products will be further disposed into waste management.

\section{Waste management}

At any stage of the RL process, an organisation may decide that the products have no residual value, are obsolete or unsalvageable or are not safe to consume, leading to the dumping of those items at a landfill (Arrieta 2015:13; Dat et al. 2012:6831). A landfill is a controlled environment where waste can be dumped and covered by earth in a safe and legal manner (Khor \& Udin 2013:73; Kinobe et al. 2015:82). Dumping of products is usually undertaken when those products are not safe to consume and where the organisation would prefer to protect their image (Kinobe et al. 2015:82; Rogers et al. 2012:107). If products are safe to consume, but the organisation has no value for them, they will be donated to charities, welfare organisations or the community, free of charge (Holweg et al. 2016:650; Negi \& Anand 2014).

\section{Drivers of reverse logistics}

The driving forces of RL practices may stem from internal or external factors.

\section{Internal drivers}

Internal drivers of RL practices relate to the factors that motivate the organisation to have an RL operation, by increasing revenue and profit through cost-saving initiatives (Hsu, Tan \& Mohamad Zailani 2016:88; Stoyanov 2012:12). The following section discusses the possible internal drivers to RL practices.

Economic drivers: Traditionally, organisations had an openloop supply chain that focussed mainly on the forward flow of products and services; however, in today's organisations, incorporating RL practices into a closed-loop supply chain may allow for cost saving and revenue opportunities (Das \& Dutta 2013:725; Zhou et al. 2011:352). Recapturing the value of returned products through reuse and recycling serves as a revenue enhancement opportunity for organisations (Govindan, Soleimani \& Kannan 2015:603; Nikolaou et al. 2013:173). RL practices, such as recycling, have been receiving increased attention, as opportunities to reduce the cost of production using recycled inputs exist (Choudhary \& Seth 2011:4988; Huang et al. 2013:515; Lee \& Lam 2012:591). In a highly commoditised industry where repurchase behaviour is determinant on price, using RL practices to create cost savings is a critical tool (Marchi et al. 2013:70).
The second-hand market also offers cost-saving opportunities, as product returns can be sold to consumers at lower prices after being returned, reducing those products' potential lost cost (Lee \& Lam 2012:591; Rogers et al. 2012:108). For example, passed sell-by-date products at retail stores may be sold to employees at discounted rates, allowing for some product-related cost recovery (Alexander, Gregson \& Gille 2013:475). Alternatively, providing backhaul services for suppliers can also be a method for an organisation to generate additional revenue streams (Larsen \& Jacobsen 2016:787; Nikolaou et al. 2013:173).

Competitive drivers: RL practices allow the organisation to remain competitive by reducing inventory levels through product recovery, thus reducing the organisations' inventory carrying costs (Barcos et al. 2013:582; Lee \& Lam 2012:596). In a highly commoditised industry, using recycled inputs will allow the organisations to lower the cost of products and remain competitive in the industry, while satisfying customers through lower prices (Chan et al. 2012:1320; Mafakheri \& Nasiri 2013:187). RL practices such as reuse, remanufacturing and recycling allow organisations to improve their image among customers, by maintaining an environmentally sustainable image (Chan et al. 2012:1320; Zhang, Zhou \& Leromonachou 2013:111). According to Wang, Zhou and Ren (2010:336), customers may show an organisation preference when they have environmentally sustainable practices over the organisations that do not perform such RL practices.

Operational performance drivers: By effectively managing RL practices, organisations can reduce transportation, waste disposal as well as inventory carrying costs (Dües, Tan \& Lim 2013:96; Sobral, Sousa Jabbour \& Chiappetta Jabbour 2013:70). Returned products that are reinserted into the forward flow can allow the organisation to generate additional revenue, reduce operating costs and minimise the opportunity costs of disposing defective or obsolete products (Dües et al. 2013:96; Sobral et al. 2013:70). The above-mentioned RL practices allow the organisations to conserve resources and lower their resource investment, thus allowing for the conservation of inputs and an overall increase in the organisations' operational efficiency (Govindan et al. 2012:204; Lai \& Wong 2012:268). The increase in operational performance may enable organisations to gain a competitive advantage over their rivals (Rahman \& Subramanian 2012:240; Lai, Wu \& Wong 2013:106).

\section{External drivers}

External drivers of RL focus on the triple bottom line, and typically enable the organisation to enhance customer value perceptions (Diabat \& Govindan 2011:661; Stoyanov 2012:12). The following section discusses the possible external drivers for RL practices.

Legal drivers: It has become increasingly common for countries to enforce extended producer responsibility laws that pertain to the manufacturer's responsibility for handling 
the cost of disposal, collection and reuse of end-of-life products (Alumur et al. 2012:67; Lamsali 2013:33). Strict environmental legislation on hazardous substances, packaging waste and the recovery of packaging material are enforced to hold producers responsible for the product during the entire product life cycle (Nikolaou et al. 2013:173; Zhang et al. 2013:110). These laws are therefore driving forces behind RL operations, in order for organisations to avoid prosecution (Atasu \& Subramanian 2012:2; Kannan et al. 2012:75).

In the grocery retail industry, food quality and safety can have a major implication on customer health; thus, proper product disposal is essential for reducing any customerrelated health issues (Aung \& Chang 2014:173; Manzini \& Accorsi 2013:251). Defective products may harm consumers; therefore, it is critical to enforce high-quality product standards (Atasu \& Subramanian 2012:2; Kapetanopoulou \& Tagaras 2011:152).

Environmental drivers: Environmental management is a key strategic issue that has the potential of impacting organisational performance (Dey, LaGuardia \& Srinivasan 2011:1248; Diabat \& Govindan 2011:659). Recently, a culture of consumerism ideology has contributed to a large amount of waste, thus putting stress on resource sustainability (Arrieta 2015:1; Nikolaou et al. 2013:178). Product recovery may reduce the effect of this ideology, by recycling or reusing products, in order to reduce the amount of packaging and waste (Arrieta 2015:1; Nikolaou et al. 2013:178). Using recycled or recovered materials for inputs allows the organisation to reduce their carbon footprint and save on energy costs (Dey et al. 2011:1248; Diabat \& Govindan 2011:659). Furthermore, reuse, recovery and effective waste management may enable the organisation to improve their image, as customers are more sensitive towards environmental issues and sustainability (Bernon et al. 2011:494; Zhu \& Geng 2013:6). For example, RL practices contribute to environmental improvement by reducing the energy use and $\left(\mathrm{CO}_{2}\right)$ emissions per item, as well as the road vehicle kilometres per sale (Nikolaou et al. 2013:178).

Social responsibility and corporate citizenship drivers: Corporate social responsibility is a professional code of conduct that is enforced because of customer pressure or stakeholder demands (Öberseder, Schlegelmilch \& Murph 2013:1840; Pishvaee, Razmi \& Torabi 2012:1). A sustainable image is essential when producing or marketing a product; thus, enforcing RL practices enables organisations to maintain a favourable public image and increase customer loyalty (Eltayeb \& Zailani 2011:382; Lamsali 2013:34). Increases in governmental and societal demands for sustainability present a need for green principles to be present in every aspect of an organisation (Eltayeb \& Zailani 2011:382; Lamsali 2013:34). For example, an organisation may receive pressure to increase the amount of recycling and production of biodegradable products, which helps improve the sustainability of the environment (Bhattacharjya, Baruah \& Satapathy 2015:432; Rahman 2013:2).

\section{Barriers to reverse logistics}

The following section addresses the internal and external barriers to RL practices.

\section{Internal barriers}

An internal barrier relates to a hindrance within the organisation that affects the performance of RL practices (Abdulrahman et al. 2014:461).

Lack of functional integration: RL practices often suffer from a lack of functional communication and cooperation (Abdulrahman et al. 2014:463; Sharma et al. 2011:102). Internal integration builds on the premise that various functions in the organisation should work collaboratively as a single entity, ensuring that mutually acceptable outcomes are achieved and contribute to the continued success of the RL practices (Bernon et al. 2013:601; Hazen et al. 2012:247). Differing views on the importance of RL are, however, shared; resulting in poor functional integration, as well as higher product return rates (Abdulrahman et al. 2014:466; Bernon et al. 2011:485; Ye et al. 2013:140). If the functions that are involved in RL practices do not understand the end goal of RL, competing goals and objectives will be set across departments (Badenhorst 2013a:54).

Top managements posture on Reverse logistics: Management may also not be committed to RL because they are not aware of the resulting benefits that could accrue (Hazen et al. 2012:248; Ho et al. 2012:33). Top managements posture and role in the decisions ensure congruent views on RL, allowing for the appropriate resources to be dedicated to the effective performance of RL practices (Creutz \& Larsson 2012:27; Ye et al. 2013:134). In order to gain organisational benefits from RL practices, RL experts who are personally committed and responsible for the creation and implementation of RL strategies should be placed in the organisation (Ho et al. 2012:33; Vijayan et al. 2014:19).

Financial barriers: Lack of initial capital and funds for returns monitoring systems, storage and in-house handling of returns are a major barrier to RL practices (Abdulrahman et al. 2014:461; Sharma et al. 2011:102). Conducting RL practices are a precarious endeavour for top management, as they involve financial aspects that may impact the organisations' long-term performance (Ganjali, Shirouyehzad \& Shahin 2014:52). The information systems that are critical to track and trace product returns and recoveries are critical to the success of RL operations, but require large amounts of capital and resources to implement and maintain (Bernon et al. 2011:495; Ho et al. 2012:33; Sharma et al. 2011:103).

An effective RL operation requires personnel to be trained; however, this training requires financial support that the organisation may not possess or want to dedicate to RL, thus creating great difficulty in managing the RL practices (Sarkis, Zhu \& Lai 2011:8; Sharma et al. 2011:102). Education and training are major requirements for success in an organisation; therefore, the more well-trained staff available, the greater 
the efficiency of the RL operation (Creutz \& Larsson 2012:13; Sharma et al. 2011:102).

Lack of sufficient information systems: Implementing and maintaining a product return system requires strategic planning and investment in additional facilities, personnel and operating activities, which is ultimately viewed as a costly sideshow, especially if the products are not saleable afterwards (Piplani \& Saraswat 2012:1428; Ye et al. 2013:135). The lack of or incompatibility of information technology systems to effectively transfer product return information between the involved parties acts as a major barrier to RL practices, as the data quality and responsiveness of partners are compromised when returns have to be handled manually (Bernon et al. 2013:601; Ganjali et al. 2014:52; Madaan, Kumar \& Chan 2012:449). To ensure integrity and consistency of the RL process, an easily accessible, shared platform where supply chain partners can share information on customers, inventory and logistics is necessary (Lambert et al. 2011:562; Shi et al. 2012:228).

\section{External barriers}

An external barrier refers to an outside influence effecting the organisations RL practices, such as a government policy (Abdulrahman et al. 2014:461).

Supply chain partner integration: Supply chain partners are said to be the motivators of RL practices, thus emphasising the need for close, integrative supply chain relationships among partners (Ho et al. 2012:42; Shi et al. 2012:225). External integration refers to the integration between a focal company and its external environment, and may take place at different levels of the supply chain (Bernon et al. 2013:588; Cardoso, Barbosa-Póvoa \& Relvas 2013:438). Noncooperation of supply chain partners to RL practices and organisational policies are one of the main barriers to RL, and if removed, the chances of effective RL practices will be much greater (Ho et al. 2012:33; Sharma et al. 2011:103). Considerable time, money and effort are spent on developing a complex product return system that relies on supply chain collaboration and integration to perform effectively; however, poor integration between supply chain partners can result in the return system being a key cost driver (Bernon et al. 2013:593; Ye et al. 2013:140)

Lack of accurate forecasting: The lack of accurate forecasting between supply chain partners acts as a major barrier for RL because of the difficulties in planning for the quantities and diversity of products that need to flow through the reverse chain (Cardoso et al. 2013:446; Sharma et al. 2011:103). Product returns are the most common aspect of RL; however, they introduce uncertainty into the organisation, as the timing, disposition, condition, quality and quantity of the returns are unknown (Badenhorst 2013b:4; Shaharudin, Zailani \& Tan 2014:5). Infrequent and erratic timing patterns create organisational uncertainty, as to what will arrive daily at the facility (Badenhorst 2013b:4; Shaharudin et al. 2014:7). Decisions that are accompanied by accurate information play an effective role in the management and improvement of product flows, and enable a more efficient and profitable RL operation (Govindan et al. 2015:617; Madaan et al. 2012:449). Efficient information systems are capable of providing the end-to-end visibility that is needed to reduce forecasting uncertainty (Rahman \& Subramanian 2012:243; Vijayan et al. 2014:12).

Government support and policy: Government policy and financial support can play a major role in an organisation's RL practices, as the lack of enforceable environmental laws established by the government reduces the incentive and motivation for organisations to perform RL practices (Ganjali et al. 2014:53; Ho et al. 2012:33). A lack of tax policies and financial support from government to subsidise RL has acted as a disincentive for organisations to invest and or collaborate in RL practices, as the products brought back into the reverse chain create high degrees of tax complexity and exposure (Abdulrahman et al. 2012:469; Sharma et al. 2011:103). It is therefore government policy that has the greatest external influence on an organisation's RL practices (Lai \& Wong 2012:269; Ye et al. 2013:133).

\section{Reverse logistics as a competitive advantage}

In a highly commoditised industry where costs are one of the most important factors to customers, lower prices may increase the organisations market share and customer repurchase behaviour (Cuneo, Lopez \& Yague 2012:434; Glanz, Bader \& Iyer 2012:506). RL practices allow organisations to benefit from additional cost-saving opportunities by recovering the costs of product materials and reusing them at a later stage (Arrieta 2015:18; Chan et al. 2012:1320). Cost savings can be transferred into the price of the products, thus allowing the organisation to remain price competitive (Akdoğan \& Coşkun 2012:1643; Arrieta 2015:17). Because of the fact that organisations in the grocery retail industry have high amounts of waste, cost savings can be achieved through social initiatives, such as charity pickups. Local charities can help the organisation reduce the transport cost associated with returning perishables to a DC or landfill by picking up the food that is past its sell-by-date (Garrone, Melacini \& Perego 2014:1462; Negi \& Anand 2014). Past-sell-by-date perishables can also be sold to pig farmers for food, or used as compost in the agricultural sector, thus reducing the products potential lost cost (Hirsch \& Harmanci 2013).

Conducting backhaul activities can also generate revenue streams and allow the organisation to improve the efficiency of their fleet utilisation, ultimately reducing the cost of transportation and the end product (Larsen \& Jacobsen 2016:784; Hsu et al. 2016:92). The ability of the organisation to develop a competitive advantage from RL practices may stem from the organisations effectiveness and efficiency in conducting RL practices on a day-to-day basis (Akdoğan \& Coşkun 2012:1643; Ye et al. 2013:134). 


\section{Methodology}

\section{Research design}

In this study, a deeper understanding of the RL process of each organisation along with their internal and external drivers and barriers of RL practices is required; thus, a generic research design was most fitting (Lambert \& Lambert 2012:255; Plano Clarke \& Creswell 2015:289). Generic qualitative research is suited when the researchers seek to understand a phenomenon, process or the opinions of many different individuals (Caelli, Ray \& Mill 2003:2; Sandelowski 2000:335). As the researchers only interviewed the participants once, the study was cross-sectional in nature (Zikmund et al. 2013:178).

\section{Sampling}

The unit of analysis in this study was the RL practices of the participating South African grocery retailers. Twelve employees from four different large grocery retail organisations, in the South African grocery retail industry, participated in this study. A total of three semi-structured interviews were conducted per organisation. All of the participating organisations have regional offices in Gauteng. From an organisational perspective, homogenous sampling was used to identify the selected grocery retailers (Bazeley 2013:49; Zikmund et al. 2013:393). This sampling method was the most appropriate, as there are only a limited number of large South African grocery retailers, thus allowing the researchers to purposefully select all of those organisations and eliminate any other smaller grocery retailers. The organisations had to be operating in the South African grocery retail industry, as well as perform RL practices, which were confirmed by making phone calls to each organisation. The RL practices did not have to be performed in-house, but could also be outsourced, for the organisations to participate in this study.

A homogeneous sampling strategy was used to identify individual participants based on their job title and their involvement in the RL practices of the organisation (Plano Clarke \& Creswell 2015:334; Yin 2015:88). For an individual to be included in this study, they needed to have a minimum of 1 year's experience within the organisation and be actively involved in the organisation's RL practices. The inclusion criteria were set out to ensure that the researchers obtained high-quality data from the most appropriate individual. A total of one senior manager and two middle managers were selected per retailer in order to obtain several managerial perspectives and opinions on the phenomenon under study. The senior managers who participated in the study were predominantly general managers, with one participant being a logistics director. The middle managers were primarily involved in the operations, administration or the quality of the RL service that was provided by the participating organisations.

Because of its nature of referrals, a snowball sampling strategy was also used in order to gain access to other appropriate individuals within each organisation (Neelankavil 2015:231; Zikmund et al. 2013:401). Generally, the researchers conducted one or two interviews and were then referred to the other employees, allowing for greater value to be added to the study, because of a greater understanding of the content of the questions posed. The final sample size was determined by the guidelines of Guest, Bunce and Johnson (2006:61), which state that 6-12 interviews are sufficient for the development of meaningful themes and valuable interpretations. When recurring information started to appear from Interview 9, the researchers decided to conduct three more interviews, albeit ending data collection. The details of the participants are provided in Table 2.

\section{Data collection}

Data were collected by conducting face-to-face semistructured interviews at the participants' offices. A total of 11 face-to-face semi-structured interviews and one telephonic interview were conducted, lasting an average of $34.20 \mathrm{~min}$ each. F2 did not have an appropriate individual for the study in Gauteng, thus ensuring value optimisation; a participant from the Cape Town head office was telephonically interviewed. This method allowed the researchers to extract extensive information and opinions, as well as gain a comprehensive understanding of the RL phenomenon under study (Farquhar 2012:10; Gill et al. 2008:292; Yin 2014:76).

TABLE 2: Participants' profile information.

\begin{tabular}{|c|c|c|c|c|c|c|}
\hline Participant & Firm & Job title & Gender & Age & Years in industry & Duration of interview ( $\mathrm{min}$ ) \\
\hline P1 & F1 & General Manager & Male & 47 & 9 & 31.36 \\
\hline P2 & F1 & Site Inventory Manager & Male & 40 & 4 & 29.05 \\
\hline P3 & F1 & Assistant Finance Manager & Female & 24 & 2 & 21.20 \\
\hline P4 & $\mathrm{F} 2$ & General Manager & Male & 45 & 14 & 56.10 \\
\hline P5 & $\mathrm{F} 2$ & Transport Services Manager & Female & 28 & 5 & 16.03 \\
\hline P6 & $\mathrm{F} 2$ & Transport Services Manager & Male & 29 & 2.1 & 45.58 \\
\hline P7 & F3 & Logistics Director & Male & 59 & 25 & 36.37 \\
\hline P8 & F3 & Reverse Logistics Controller & Male & 45 & 20 & 46.41 \\
\hline P9 & F3 & Inventory Manager & Male & 39 & 16 & 35.24 \\
\hline P10 & $\mathrm{F} 4$ & General Manager & Male & 32 & 8 & 36.29 \\
\hline P11 & F4 & Supply Line Manager & Female & 28 & 5 & 10.46 \\
\hline P12 & F4 & Administration Manager & Female & 55 & 35 & 46.27 \\
\hline Average & - & - & - & - & - & 34.20 \\
\hline
\end{tabular}


Grounded in the initial literature review, the discussion guide consisted of key open-ended questions accompanied by additional probes, which attempted to address the research questions of the study (Myers 2013:122; Turner 2010:755). In order to ensure that the discussion guide was in a more conversational tone and was easily understood by the participants, a pretest and a pilot test were conducted with a supply chain management academic and an inventory manager within a South African grocery retailer, respectively. The interviews were all recorded using multiple recording devices. All of the recordings were sent to a professional transcription service upon interview completion. Upon transcript completion, the transcripts were compared to the actual recordings and necessary changes were made, thus ensuring a verbatim account of the interviews that took place.

\section{Data analysis}

Thematic analysis, which is a method used to classify, identify and order important pieces of unstructured text, was used in this study (Alhojailan 2012:40; Braun \& Clarke 2012:57). Preliminary exploratory analysis then took place, with the researchers listening to the recordings and reading the transcripts simultaneously, to allow for data familiarisation (Creswell 2012:243). The researchers then coded the transcripts independently by adding key words to the applicable text and then undertaking comparison to identify similar codes and themes. A master codebook was developed to enhance parallelism and the codes were reapplied to similar data segments to reduce redundancy (Braun \& Clarke 2012:61). After coding, the codes were grouped into major themes that link back to the literature, as well as emerging themes that relate to the studies' research questions (Creswell 2012:243; Saldaña 2015:9).

\section{Trustworthiness}

Peer debriefing with an experienced supply chain management academic was used to enhance the quality of the approaches used and ensure validity (Polit \& Beck 2012:594; Shenton 2004:67). To ensure confirmability, both data and site triangulation were employed by gaining participation from multiple participants and organisations, which allowed for the convergence of evidence and strengthening of the constructs (Rossman \& Rallis 2011:65; Yin 2014:121). The provision of a thick description of the study's context and participants, as well as the inclusion of the utilised discussion guide and data analysis process allows for further assessment of the study's transferability (Polit \& Beck 2012:596; Shenton 2004:70).

\section{Findings}

The research identified five main themes relating to the proposed research questions as evident from Table 3.

\section{Reverse logistics practices}

RL practices refer to the return, reuse, recovery or the wasting of products within an organisation, each with their own underlying concepts that were uncovered and are explained

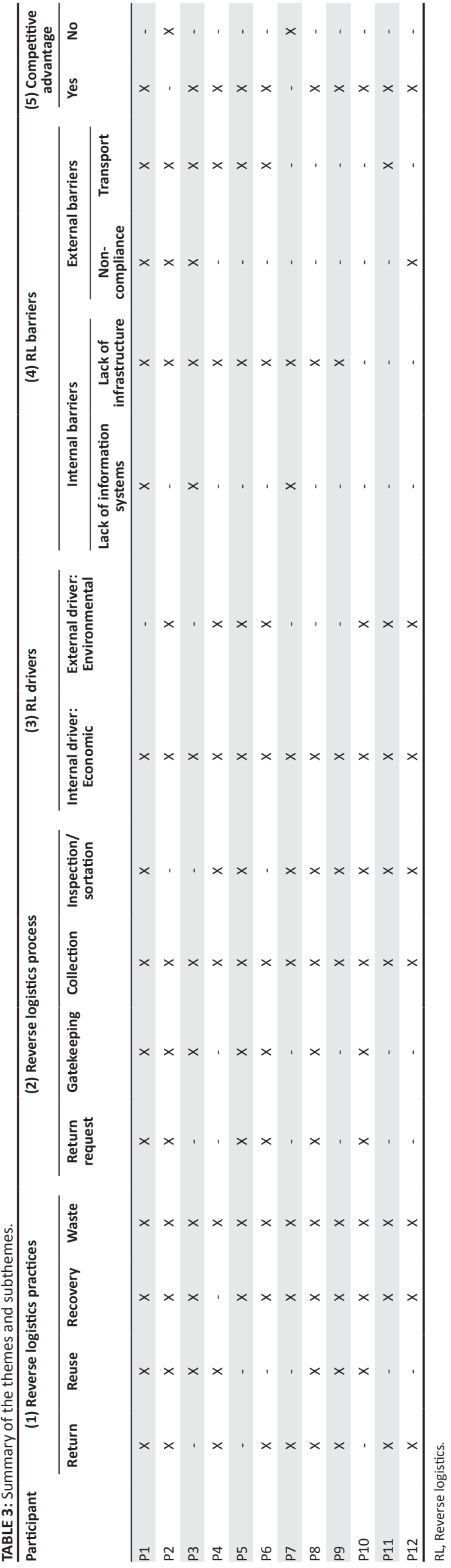


in the following section (Dat et al. 2012:6381; Lambert et al. 2011:562).

\section{Product returns}

Product returns consist of manufacturer and vendor returns in this study. Manufacturer returns occur because of failures of product quality on arrival at the retailer's DC or retail store, as well as damaged stock that must be returned (Chopra et al. 2012). Technologists and clerks check the standard of the product that is delivered in order to determine if that stock can be received:

We'll get to the store, the store will do the temperature probes with the driver etcetera, front, middle, back, top, bottom; sorry boet, this thing is not meeting the specs we've got to reject these products. (Participant 4, male, general manager)

Vendor returns also occur when products are not selling at retail level or get damaged within the warehouse or retail store and are either dumped or sent back to the vendor for value recovery:

Once it is here [at the $D C$ ] we can either choose to dump it on your behalf, you carry the cost, or you want the product back because your packaging is valuable to you, you come and collect. (Participant 10, male, general manager)

This finding is in line with the reviewed literature that states that when a product fails a quality check, it is returned to the manufacturer to be reworked to a specific standard (Zhao et al. 2013:115).

\section{Direct reuse}

Selling products at a discounted rate to a second-hand market or reusing them in other areas are ways that organisations can recover costs on items that are no longer saleable in stores:

There is one lady who has got a store just actually in Modderfontein that is supplying salvage stock, so she is buying from a whole bunch of different places and she has got her store specifically on that. (Participant 2, male, site inventory manager)

Some of the stores will take it [damaged bags] if there is a small tear in it, and use it in their in-house bakery. (Participant 1, male, general manager)

These observations fall in line with the reviewed literature that states that damaged items may be reused in other organisational areas or resold to third parties, thus enabling cost recovery (Holweg et al. 2016:651; Silva et al. 2013:379).

\section{Product recovery management}

Because of the fact that there is a large amount of damage within a DC environment, reworking operations make up a large portion of product recovery. If damaged articles are not reworked into the system, they will be disposed, resulting in negative effects on the organisational profitability:

So what they will do is, they will break that pack, they will take the dented tin out and isolate it, that goes back to the supplier. Then you might have a twelve pack of cream style mealies, okay. They will take a can of mixed vegetables, and put it in the Koo beans, makes up a twelve pack, back to pick phase, out to stores so they basically rework it. (Participant 12 , female, administration manager)

The short shelf life of grocery products is not favourable to recycling; therefore, most organisations in the grocery retail industry focus on recovering costs or generating additional revenue from recycling product packaging:

So there is a second hand box market that no one really looks at. There are suppliers like Simba they actually let their reps get 50 cents or a value, last time I think it was like 50 cents per box if they are returned back to the factory. Because it is a light product, it does not damage. And if you handle it correctly you can use the box three, four or five times. (Participant 10, male, general manager)

Reworking damaged articles into saleable batch sizes, in order to optimise value recovery, is in line with the reviewed literature (Dat et al. 2012:6381). Focussing on recycling packaging as a revenue enhancement opportunity is, however, contrary to the literature, as the reviewed literature mainly focusses on recycling products as a cost recovery strategy (Akdoğan \& Coskun 2012:1643).

\section{Waste management}

Waste management pertains to the disposal, donation or return of a product to a vendor for their own disposal (Lambert et al. 2011:562; Nikolaou et al. 2013:176). There is no revenue value within waste management, as the products are either given away or disposed. Because of the hardship hitting the South African community, organisations prefer to donate as much product to various entities as possible, before resorting to disposal:

Each division will have certain charities that they provide waste and etcetera to, that's how they will handle it. (Participant 4, male, general manager)

Products that are not donated are disposed of in a landfill environment or sent back to the vendor for their own disposal. The waste management process is very strict, and disposal certification is required to ensure the legal protection of the organisation. Products that have reached their expiry date or have been rejected due to temperature problems are immediately disposed, limiting the possible effect that those products could have on any consumer:

As long as it's in between the sell by date and expiry date, we can still give it away, but if it is over the expiry date, then we destroy it. (Participant 5, female, transport services manager)

The findings confirm the reviewed literature, stating that a product with harm causing potential will be dumped; however, an item with no organisational value will be donated free of charge (Negi \& Anand 2014).

\section{Reverse logistics processes}

An RL process refers to the upstream flow of goods in a supply chain and involves a number of processes, namely customer return request, gatekeeping, collection, inspection 
and sortation, as well as disposition (Agrawal et al. 2015:77; Tan \& Chanchaichujit 2016:11). In the selected grocery retailers, the process begins with a customer return request where the organisation is notified of a potential return:

So the store, it will flag itself on the system, the system will note that this item is not moving as fast as it should be. Please arrange to have it sent back to the distribution centre. (Participant 6, male, transport services manager)

A gatekeeping process is then performed, which entails the product being cleared for return (Rogers et al. 2012:108). Once the gatekeeping process is completed, the items can be returned to the applicable facility:

We have a process where a ticket is logged from a call centre perspective. We call it a GRN [goods received note], as generated through someone at the DC claims department; a returns order is printed at the store the driver signs for it; gets handed back again, now he can collect it and it comes back to DC. (Participant 1 , male, general manager)

Inspections and sortation are then undertaken to determine the product quality and sort the items into categories (Agrawal et al. 2015:77). This process is undertaken to ensure the quality of the items that are fit for return, and reduce the number of returns entering the DC for illegitimate reasons:

We will then investigate what product, the product that was returned, what is actually usable, what is not usable, and honour the claim with the guys, so their stock ledger is sorted out...you don't want something sent back with zero value. (Participant 10, male, general manager)

Products can then be reused, recovered or wasted; therefore, a disposition process needs to take place in order to place those products in the appropriate RL practice. The RL department is usually responsible for those decisions:

Either it is good for, as a saleable or it needs to be dumped. They [reverse logistics managers] will make that call. (Participant 9, male, inventory manager)

The process that is followed by the selected grocery retailers corroborates with the reviewed literature, which found that organisations follow a process of requesting, gatekeeping, collection, inspection or sortation and then disposition (Agrawal et al. 2015:77; Lambert et al. 2011:561).

\section{Drivers of reverse logistics}

The drivers of RL can originate internally from within the organisation or from external sources outside of the organisation (Beske, Land \& Seuring 2014:131).

\section{Internal drivers}

An internal driver is a motivating factor for RL that originates from within the organisation (Nikolaou et al. 2013:174). Economic drivers were identified by all 12 of the participants in this study.

Economic driver: Recovering cost and generating additional revenue streams through $\mathrm{RL}$ were the main economic drivers for RL practices within this study. Whenever there is heavy machinery involved in processes, damage is likely to appear. Without the RL process, the damaged products would need to be immediately disposed of, eliminating any chance for product and cost recovery:

When there is machinery, believe it or not, you'll have damages. And if you don't have anything to recover those damages, your expenses will shoot off the roof and you've got nothing to counter back those expenses. Reverse logistics is all about recovery. (Participant 9, male, inventory manager)

This finding is in line with the reviewed literature that states that RL practices such as reworking allow the organisation to recover some of the products' value (Lee \& Lam 2012:591). Essentially, the idea of recovering costs is to transfer those cost savings into the price of the product and remain price competitive within the industry. The greatest area of cost saving seems to originate from greater efficiency within transport, where organisations prefer to collect from suppliers on return legs to reduce the final transport cost:

I deliver there [Boksburg] on a daily basis. Can we look at collaborating and say, if I collect from you, can you have a price reduction? And then we become cheaper for our clients, and then the preferred retailer. (Participant 10, male, general manager)

Conducting RL can also generate a revenue stream. Additional revenue will positively impact the organisational profit margins and can be used to fund capital-intensive projects as well as increase the efficiency and the utilisation of the transport fleet:

You are generating revenue. It is a revenue stream that enables you actually to get funding and increase your efficiency. So you realise that you need to fund a new machine that is going to be washing your equipment instead of going out to ask for money, using reverse logistics I can raise ten million rand so I can maybe I can then just ask for half the money. And we have more cash flow to use for other things as well. (Participant 6, male, transport services manager)

The previous two observations, however, do not completely fall in line with the reviewed literature. The literature states that RL practices enable an organisation to transfer cost savings into the price; however, there was no mention of using a more efficient transport system to gain those cost savings (Marchi et al. 2013:70). Reviewed literature also mentions a revenue stream that can be generated from conducting backhauls; however, there was no mention of funding capital projects with that additional revenue, and thus this observation differs from that of the literature (Larsen \& Jacobsen 2016:787).

\section{External drivers}

An external driver is a driving factor that originates from outside of the organisation for RL practices (Diabat \& Govindan 2011:661). Environmental drivers were the main external driver that was uncovered in this study.

Environmental driver: Large organisations have huge amounts of infrastructure that create negative effects on the 
environment; however, there is an expressed need by all four grocery retailers to reduce the organisation's impact on the environment. RL is used as a method to reduce the number of vehicles on the road and the kilometres that those vehicles travel, thus causing less carbon emissions and congestion on the roads (Nikolaou et al. 2013:178). There is also a constant progression towards continuously improving processes and machinery, in order to reduce that negative effect on the environment and drive a more sustainable future:

We're always looking into new developments on the engines and fuel efficiencies and then also the fridge, the company that does our fridges on the bodies, also seeing what kind of gas we can use a little better; uses of diesel, we also actually looking at changing our branding because the black trucks uses more diesel. (Participant 5, female, transport services manager)

This finding is in line with the reviewed literature that states that organisations can increase their environmental sustainability and reduce their carbon footprint by conducting RL practices (Zhu \& Geng 2013:6).

\section{Barriers to reverse logistics}

\section{Internal barriers}

An internal barrier relates to a hindrance within the organisation that affects the efficiency of RL practices (Abdulrahman et al. 2014:461). A lack of information systems and infrastructure were the two internal barriers that were identified in this study.

Lack of sufficient information systems: In line with the reviewed literature, there is a general lack of RL information systems that are used in the selected grocery retailers (Ganjali et al. 2014:52). Three participants mentioned that the RL process is exceedingly manual, which creates many loopholes for pilferage and incorrect processing of returns. The lack of RL information systems creates poor return visibility, as well as a culture of inefficiency within the RL process:

I would definitely think [electronic] capturing because it is still a very manual process. So the documents and your invoices and everything, it's manually captured. So sometimes they will capture a duplicate, or sometimes they won't capture it at all. (Participant 3, female, assistant finance manager)

Lack of infrastructure: Eight participants identified the lack of physical infrastructure as an internal barrier. Because of the size of the organisations in this study, a large amount of waste is generated on a daily basis. Waste, be it products or packaging, needs to follow a disposition strategy, where it will be recycled, reused, dumped or donated (Hazen et al. 2012:248). There is a lack of infrastructure at retail level to handle to RL practices:

We collect a couple of those [recyclable items] back to the DC because they just don't have the infrastructure and it comes back to us, into our recycling process. (Participant 7, male, logistics director)
There is also a lack of storage space for those returned recyclables and products within the DC, thus emphasising the importance of vendor upliftment policies:

Obviously you need to balance between how much space have I got in my warehouse to store the stock and when are they are going to uplift it, because I do not want to sit with ten or fifteen pallets in then we will uplift. It is just going to take up space. Space is really something we do not have in the warehouse here. (Participant 2, male, site inventory manager)

The above observations differ from the reviewed literature, as the literature focuses more on the lack of systems infrastructure, rather than actual storage space for the handling of the returns process (Sharma et al. 2011:102).

\section{External barriers}

An external barrier refers to an outside influence that affects organisations' RL practices (Abdulrahman et al. 2014:461). Supplier policy and non-compliance, as well as transport, are the main external barriers that were identified in this study.

Supplier policy and non-compliance barrier: Four participants reported incidents of suppliers over packing pallets and not adhering to upliftment policies within the DC. Pallets that are incorrectly packed are more susceptible to damage, thus creating a direct need for RL practices:

... articles that are mostly damaged within the DC and that's because of poor packaging and overhanging on pallets. (Participant 1, male, general manager)

This finding confirms the reviewed literature, which states that non-cooperation of supply chain partners to RL practices and organisational policy is a major RL barrier (Ho et al. 2012:33).

Transport barrier: When dealing with hundreds of suppliers, each with their own transport provider, issues are likely to result. Many suppliers do not specialise in transport, thus opt for the cheapest alternative available, without recognition of the possible consequences. Organisations often utilise thirdparty transport providers whose drivers do not understand the steps that need to be taken regarding the RL process, resulting in loss or misunderstandings between the store and the DC:

We use a 3PL ... I don't believe that the drivers, and they make use of 3 code drivers, and sometimes its temps, they don't know how; they don't know what to check what documentation needs to be signed. (Participant 1, male, general manager)

The reviewed literature mentions increased costs because of a lack of systems integration between supply chain partners (Ye et al. 2013:140). This observation differs from that literature as a lack of supplier transport understanding introduces unnecessary inefficiencies and costs into the RL system. 


\section{Competitive advantage}

Ten of the participants stated that RL practices do enable their organisation to achieve a competitive advantage. RL practices offer the organisation opportunities to reduce their costs, as well as inefficiencies within the organisation:

I think so, yes. Say by picking up the damages from the stores, bringing it back to a centralised facility. Now we reduce congestion at our stores. We do not have trucks standing in line to pick up their damages or returns or expired stock or whatever. It gives you a cost advantage, it gives you a time advantage, you can get product in faster, at a cheaper rate. (Participant 11, female, supply line manager)

The remaining two participants specified that RL is a necessary part of day-to-day life, but does not provide the organisation with a competitive advantage over their competitors:

It $[R L$ practices] is such a small part of our day to day life ... it is a necessity and sometimes it is, to say it is something that we deal with on a day to day basis when we have to deal with it. (Participant 2, male, site inventory manager)

The finding that RL can enable an organisation to achieve a competitive advantage by conducting various product recovery and revenue generation initiatives is confirmed in the literature (Cuneo et al. 2012:434). The notion that RL is just a necessary part of day-to-day life, however, is not confirmed by the reviewed literature.

\section{Ethical considerations}

A research ethics committee at a South African university approved this study. The participants read and signed an informed consent form, which explained the purpose of the study and indicated that participation was voluntary and that participants could leave at any time. Anonymity of individual and organisational details was ensured by the use of pseudonyms, thus encouraging greater honesty in the responses that were provided by the participants.

\section{Conclusion}

\section{Summary of findings and theoretical implications}

The aim of this generic qualitative study was to identify the main internal and external drivers and barriers of RL practices within the South African grocery retail industry. A number of conclusions have been drawn relating to the studies research questions. All participating organisations have implemented some sort of return, reuse, recovery or waste management practices within their organisation. The most common practices in the industry are returns to vendors, reworking of damaged items, third-party sales and donations of products, as well as disposal of unsalable products. All the above practices are in line with the reviewed literature; however, remanufacturing does not take place, because of the perishable nature of the products and a lack of remanufacturing facilities at the DC (Arrieta 2015:13; Lambert et al. 2011:561). Generally, an attitude of maximal product recovery and waste reduction is present within the grocery retailers, allowing the organisations to optimise their profitability. Similarly, all four organisations under review follow a similar RL process. This process consists of a customer return request, gatekeeping, collection, inspection or sortation and disposition, which fall directly in line with the reviewed literature (Tan \& Chanchaichujit 2016:11).

Economic drivers, allowing the organisation to save on costs and generate additional revenue through RL practices, were the main internal drivers that were uncovered in this study. This finding is in line with the reviewed literature that states that organisations can use RL practices to recover costs and transfer those savings into the product price, as well as generate additional revenue streams through providing backhaul services (Govindan et al. 2015:603; Larsen \& Jacobsen 2016:787). Additionally, environmental drivers were exposed as the main external driver for RL practices in the cases under review. RL practices enable the organisation to reduce their environmental impact by reducing the number of vehicles on the road, the kilometres travelled, as well as the vehicles $\left(\mathrm{CO}_{2}\right)$ emissions, which corroborate the reviewed literature (Nikolaou et al. 2013:178). Packaging and waste reduction are also optimised, thus countering the notion of a consumerism ideology (Arrieta 2015:1). Legal drivers were not present in this study, because of the fact that the cases do not have any legal obligation to implement RL practices in South Africa (Alumur et al. 2012:67; Lamsali 2013:33).

A lack of information systems and infrastructure are the two internal barriers that were identified in this study. Data integrity and consistency, as well as organisational efficiency, is compromised, as there is no shared platform where supply chain partners can share the necessary information regarding product returns (Lambert et al. 2011:562; Shi et al. 2012:228). Previous research has specified a lack of finances for training and information systems; however, this research has identified that a lack of infrastructure is a major barrier to RL practices (Creutz \& Larsson 2012:9; Piplani \& Saraswat 2012:1428). The lack of infrastructure at retail and DC level also creates difficulty in managing product returns, as there is insufficient storage space for these items. There was no evidence of a lack of functional integration and top management support regarding the RL practices within the participating retailers (Bernon et al. 2013:601; Ho et al. 2012:33).

Externally, supplier non-compliance to packing specifications and vendor upliftment policies acts as a major external barrier to RL practices, as products are more easily damaged, as well as occupy large amounts of space within the DC. Supplier transport also seems to create many issues for the cases under review, as suppliers opt for the cheapest transport alternative without recognition of the possible efficiency consequences. Third-party transport providers may also not completely understand the RL process. The reviewed literature mentions that a lack of supply chain partner integration may act as a barrier; however, it seems that the partners are integrated, but just do not follow the appropriate procedures (Badenhorst 2013a:53; Sharma et al. 2011:102). 
The majority of participants stated that RL practices do provide the organisation with a competitive advantage, by allowing them to reduce their costs and inefficiencies and generate revenue within the organisation. This finding is in line with the reviewed literature that says that organisations can be afforded additional cost-saving opportunities by conducting RL practices, as well as create additional revenue streams from providing backhaul services (Arrieta 2015:18; Larsen \& Jacobsen 2016:784). Alternatively, growth in RL practices, as well as infrastructure to perform those practices is a future priority for all the reviewed grocery retailers. This is in line with the reviewed literature, stating that organisations are more likely to dedicate substantially more resources to RL operations (Huscroft et al. 2013:319; Min \& Kim 2012:39).

\section{Managerial implications}

It is evident from this study that RL is no longer a key cost driver, but provides organisations with many additional opportunities. The opportunities for managers to grow and enhance the efficiency of their RL operation are great within the South African grocery retail industry. The findings of this study indicate that managers should continue to devote both capital and human resources to the RL operation, in order to save costs and generate additional revenue. RL operations are only going to grow in importance and are one of the keys to maintaining price competitiveness in the industry, by utilising RL practices' cost saving and recovery benefits. Damages and returns will always occur; therefore, optimising the efficiency of the RL process is essential.

The RL process creates opportunities for inefficiencies and pilferage; thus, the introduction of an information system that handles the reverse flow may be necessary. This information system will need to be easily accessed by supply chain partners and should allow for the sharing of product return information, thus increasing the receiving organisation's visibility. RL can also be viewed as an administration centre for the organisation to receive feedback with regard to product defects or reasons for return; therefore, using an information system to store that information may be a way for organisations to more critically view their operational inefficiencies and improve on them where needed. Along with an information system, managers also need to devote finances to creating more infrastructures for both forward and RL flows. The lack of infrastructure is impeding on the efficiency of the RL operation. A dedicated returns centre on the property of the main DC seems to be the most logical option to ensure optimal efficiency. Products can be dropped off at the DC for dispatch and suppliers can then uplift any product returns that have come into the facility on their way out. A dedicated returns facility will also enable the organisation to gain greater economies of scale when conducting RL practices, as all returns will be allocated to one facility.

Managers also need to realise that their suppliers have a major effect on the efficiency on the entire returns process. If the quality of the suppliers' products is below standard, it is more likely that they will be damaged or returned. It is recommended that managers introduce and enforce policies specifying upliftment and packing specifications. These policies may also be shared on the shared information system to ensure that the supplier is aware of the due procedure. A supplier's transport provider that constantly introduces delays and inefficiencies because of breakdowns and maintenance also affects the returns process. It is recommended that managers optimise their backhaul service and pick up the necessary products from suppliers on the return leg. Maintaining transport control will minimise delays, as well as increase product availability.

\section{Limitations and directions for future research}

A number of limitations have been identified in this study. Firstly, this study was dedicated to the South African grocery retail industry, disregarding all other industries within South Africa. Many of the RL practices are not conducted within the grocery retail industry. Future studies should conduct additional qualitative research within numerous industries, in order to grow the knowledge base of RL practices, within a South African context. Secondly, the sample size of this study was limited, as only four large South African grocery retailers participated in this study. The limited sample size affects the generalisability of the study; therefore, future research should focus on the drivers and barriers of RL practices in smaller grocery retailers, in order to generate a more accurate reflection of the phenomenon in this industry. Lastly, this study focussed on one tier within the supply chain, namely the grocery retailers. Future research could include multiple tiers, or focus on a different tier within the supply chain. Conducting research in the different tiers of the supply chain will allow for a more holistic perspective on the drivers and barriers for RL practices within the grocery retail industry.

\section{Acknowledgements}

The authors would like to acknowledge the reviewers of the draft manuscript.

\section{Competing interests}

The authors declare that they have no financial or personal relationships that may have inappropriately influenced them in writing this article.

\section{Authors' contributions}

J.M. and J.L. conducted the research as part of their honours degrees. A.M. and W.N. acted as the supervisors of the study and prepared the manuscript.

\section{References}

Abdulrahman, M.D., Gunasekaran, A. \& Subramanian, N., 2014, 'Critical barriers in implementing reverse logistics in the Chinese manufacturing sectors', International Journal of Production Economics 147, 460-471. https://doi.org/10.1016/j. ijpe.2012.08.003

Agrawal, S., Singh, R.K. \& Murtaza, Q., 2015, 'A literature review and perspectives in reverse logistics', Resources, Conservation \& Recycling 97, 76-92. https://doi.org/ 10.1016/j.resconrec.2015.02.009 
Akdoğan, M.S. \& Coşkun, A., 2012, 'Drivers of reverse logistics activities: An empirical investigation', Procedia - Social and Behavioral Sciences 58, 1640-1649. https:// doi.org/10.1016/j.sbspro.2012.09.1130

Alexander, C., Gregson, N. \& Gille, Z., 2013, 'Food waste', The Handbook of Food Research 1, 471-483.

Alhojailan, M.I., 2012, 'Thematic analysis: A critical review of its process and evaluation', West East Journal of Social Sciences 1(1), 39-47.

Alumur, S.A., Nickel, S., Saldanha-da-Gama, F. \& Verter, V., 2012, Multi-period reverse logistics network design, European Journal of Operational Research 220(1), 6778. https://doi.org/10.1016/j.ejor.2011.12.045

Arrieta, V., 2015, 'Reverse logistics as alleviation to ecological issues: Theory and implementation', Unpublished doctoral thesis, Helsinki Metropolia University of Applied Sciences, Helsinki, viewed 20 April 2016, from http://www.theseus.fi/ bitstream/handle/10024/93444/Valentina\%20Arrieta.pdf?sequence=1

Atasu, A. \& Subramanian, R., 2012, 'Extended producer responsibility for e-waste: Individual or collective producer responsibility?', Production and Operation Management 67, 75-79. https://doi.org/10.1111/j.1937-5956.2012.01327.x

Aung, M.M. \& Chang, Y.S., 2014, 'Traceability in a food supply chain: Safety and quality perspectives', Food Control 39, 172-184. https://doi.org/10.1016/j.foodcont 2013.11.007

Badenhorst, A., 2013a, 'A best practice framework in reverse logistics', Unpublished masters dissertation, University of South Africa, South Africa, viewed 20 April 2016 from http://uir.unisa.ac.za/xmlui/bitstream/handle/10500/10004/dissertation badenhorst_a.pdf?sequence $=1$

Badenhorst, A., 2013b, 'A framework for prioritising practices to overcome costrelated problems in reverse logistics', Journal of Transport and Supply Chain Management 7(1), 1-10. https://doi.org/10.4102/jtscm.v7i1.113

Badenhorst, A., 2016, 'Prioritising the implementation of practices to overcome operational barriers in reverse logistics', Journal of Transport and Supply Chain Management 10(1), 1-12. https://doi.org/10.4102/jtscm.v10i1.240

Banks, R., 2002, Defining and improving reverse logistics, viewed 03 June 2016, from http://www.almc.army.mil/alog/issues/MayJun02/MS745.htm

Barcos, L., Barroso, A., Surroca, J. \& Tribó, J.A., 2013, 'Corporate social responsibility and inventory policy', International Journal of Production Economics 143(2), 580588. https://doi.org/10.1016/j.ijpe.2012.04.005

Bazeley, P., 2013, Qualitative data analysis: Practical strategies, 1st edn., Oliver's Yard, Sage, London.

Bernon, M., Rossi, S. \& Cullen, J., 2011, 'Retail reverse logistics: A call and grounding framework for research, international Journal of Physical Distribution \& Logistics Management 41(5), 484-581. https://doi.org/10.1108/09600031111138835

Bernon, M., Upperton, J., Bastl, M. \& Cullen, J., 2013, 'An exploration of supply chain integration in the retail product returns process', International Journal of Physical Distribution \& Logistics Management 43(7), 586-608. https://doi.org/10.1108/ IJPDLM-03-2012-0060

Beske, P., Land, A. \& Seuring, S., 2014, 'Sustainable supply chain management practices and dynamic capabilities in the food industry: A critical analysis of the literature', International Journal of Production Economics 152, 131-143. https:// doi.org/10.1016/j.ijpe.2013.12.026

Bhattacharjya, A., Baruah, A.A. \& Satapathy, S., 2015, 'Impact of implementation of green manufacturing technology in an Indian FMCG goods industry', Advanced Technology in Engineering and Science 3(2), 432-446.

BMI Research, 2016, South Africa: Food \& drink report, viewed 05 June 2016, from https://bmo-bmiresearch/com.uplib.idm.oclc.org/reports/view?productid=538\& issue $=20160401$ \&iso=ZA\&active_pillar=Reports $\% 20$ Subtab

Bouzon, M., Govindan, K. \& Rodriguez, C.M.T., 2015, 'Reducing the extraction of minerals: Reverse logistics in the machinery manufacturing industry sector in Brazil using ISM approach', Resources Policy 46, 27-36. https://doi.org/10.1016/j. resourpol.2015.02.001

Braun, V. \& Clarke, V., 2012, 'Thematic analysis', in H. Cooper, P.M. Camic, D.L. Long A.T. Panter, D. Rindskopf \& K.J. Sher (eds.), APA handbook of research methods in psychology: Research designs: Quantitative, qualitative, neuropsychological, and biological, vol. 2, pp. 57-71, The American Psychological Association, Washington, DC

Caelli, K., Ray, L. \& Mill, J., 2003, 'Clear as mud': Toward greater clarity in generi qualitative research', International Journal of Qualitative Methods 2(2), 1-13.

Cannella, S., Bruccoleri, M. \& Framinan, J.M., 2016, 'Closed-loop supply chains: What reverse logistics factors influence performance?', International Journal of Production Economics 175, 35-49. https://doi.org/10.1016/j.ijpe.2016.01.012

Cardoso, S.R., Barbosa-Póvoa, A.P.F.D. \& Relvas, S., 2013, ‘Design and planning of supply chains with integration of reverse logistics activities under demand uncertainty', European Journal of Operational Research 226, 436-451. https:// doi.org/10.1016/j.ejor.2012.11.035

Carrasco-Gallego, R., Ponce-Cueto, E. \& Dekker, R., 2012, 'Closed-loop supply chains of reusable articles: A typology grounded on case studies', International Journal of Production Research 50(19), 5582-5596. https://doi.org/10.1080/00207543.201 1.649861

Chan, F.T.S., Chan, H.K. \& Jain, V., 2012, 'A framework of reverse logistics for the automobile industry', International Journal of Production Research 50(5), 1318-1331. https://doi.org/10.1080/00207543.2011.571929

Chopra, S., Caballero, H., Laux, C., Schmidt, E. \& Yang, H., 2012, 'Reverse logistics in the heavy machinery industry', Paper presented at 2012 Third Biennial Supply Chain Management Conference, Bangalore, India, 14-15 December, viewed 05 June 2016, from https://works.bepress.com/shweta_chopra/10/
Choudhary, M. \& Seth, N., 2011, 'Integration of green practices in supply chain environment: The practices of inbound, operational, outbound and reverse logistics', International Journal of Engineering Science and Technology 3(6), 4985-4993.

Creswell, J.W., 2012, Educational research: Planning, conducting and evaluating quantitative and qualitative research, 4th edn., Pearson, Boston, MA.

Creutz, M. \& Larsson, F., 2012, 'Reverse logistics case study comparison between an electronic and a fashion organization', Unpublished masters thesis, Jönköping International Business School, Sweden, viewed 20 April 2016, from http://www. diva-portal.org/smash/get/diva2:534434/FULLTEXTO1.pdf

Cuneo, A., Lopez, P. \& Yague, M.J., 2012, 'Private label brands: Measuring equity across consumer segments', Journal of Product \& Brand Management 21(6), 428-438. https://doi.org/10.1108/10610421211264919

Das, D. \& Dutta, P., 2013, 'A system dynamics framework for integrated reverse supply chain with three way recovery and product exchange policy', Computers \& Industrial Engineering 66(4), 720-733. https://doi.org/10.1016/j.cie.2013.09.016

Dat, L.Q., Truc Linh, D.T., Chou, S.Y. \& Yu, V.F., 2012, 'Optimizing reverse logistic costs for recycling end-of-life electrical and electronic products', Expert Systems with Applications 39(7), 6380-6387. https://doi.org/10.1016/j.eswa.2011.12.031

Dey, A., LaGuardia, P. \& Srinivasan, M., 2011, 'Building sustainability in logistics operations: A research agenda', Management Research Review 34(11), 12371259. https://doi.org/10.1108/01409171111178774

Diabat, A. \& Govindan, K., 2011, 'An analysis of the drivers affecting the implementation of green supply chain management', Resources, Conservation and Recycling 55(6), 659-667. https://doi.org/10.1016/j.resconrec.2010.12.002

Dobbs, R., Oppenheim, J., Thompson, F., Brinkman, M. \& Zornes, M., 2011, Resource revolution: Meeting the world's energy, materials, food, and water needs 03 June 2016, from http://www.mckinsey.com/business-functions/sustainability-andresource-productivity/our-insights/resource-revolution

Dües, C.M., Tan, K.H. \& Lim, M., 2013, 'Green as the new lean: How to use lean practices as a catalyst to greening your supply chain', Journal of Cleaner Production 40, 93-100. https://doi.org/10.1016/j.jclepro.2011.12.023

Eltayeb, T.K. \& Zailani, S.H.M., 2011, 'Drivers on the reverse logistics: Evidence from Malaysian certified companies', International Journal of Logistics Systems and Management 10(4), 375-397. https://doi.org/10.1504/IJLSM.2011.043101

Eltayeb, T.K., Zailani, S. \& Ramayah, T., 2011, 'Green supply chain initiatives among certified companies in Malaysia and environmental sustainability: Investigating the outcomes', Resources, Conservation and Recycling 55(5), 495-506. https:// doi.org/10.1016/j.resconrec.2010.09.003

Farquhar, J.D., 2012, 'What is case study research?', in J.D. Farquhar (ed.), Case study research for business, pp. 3-13, Sage, London.

Ganjali, M., Shirouyehzad, H. \& Shahin, A., 2014, 'Evaluating barriers of reverse logistics using DEMATEL method', Journal of Applied Science and Engineering Management 2(1), 51-61.

Garrone, P., Melacini, M. \& Perego, A., 2014, 'Surplus food recovery and donation in Italy: The upstream process', British Food Journal 116(9), 1460-1477. https://doi. org/10.1108/BFJ-02-2014-0076

Gilanli, E., Altug, N. \& Oguzhan, A., 2012, 'Reverse logistics activities in Turkey/ Türkiye'de ters lojistik faaliyetleri', Ege Akademik Bakis 12(3), 391-410. https:// doi.org/10.21121/eab.2012319526

Gill, P., Stewart, K., Treasure, E. \& Chadwick, B., 2008, 'Methods of data collection in qualitative research: Interviews and focus groups', British Dental Journal 204(6), 291-295. https://doi.org/10.1038/bdj.2008.192

Glanz, K., Bader, M.D.M. \& Iyer, S., 2012, 'Retail grocery store marketing strategies and obesity: An integrative review', American Journal of Preventive Medicine 42(5), 503-512. https://doi.org/10.1016/j.amepre.2012.01.013

Gold, S., Hahn, R. \& Seuring, S., 2013, 'Sustainable supply chain management in "Base of the Pyramid" food projects: A path to triple bottom line approaches fo multinationals?', International Business Review 22(5), 784-799. https://doi. org/10.1016/j.ibusrev.2012.12.006

Govindan, K., Palaniappan, M., Zhu, Q. \& Kannan, D., 2012, 'Analysis of third party reverse logistics provider using interpretive structural modelling', International Journal of Production Economics 140(1), 204-211. https://doi.org/10.1016/j. ijpe.2012.01.043

Govindan, K., Soleimani, H. \& Kannan, D., 2015, 'Reverse logistics and closed-loop supply chain: A comprehensive review to explore the future', European Journal of Operational Research 240(3), 603-626. https://doi.org/10.1016/j.ejor.2014.07.012

Guest, G., Bunce, A. \& Johnson, L., 2006, 'How many interviews are enough? An experiment with data saturation and variability', Field Methods 18(1), 59-82. https://doi.org/10.1177/1525822X05279903

Hazen, B.T., Cegielski, C. \& Hanna, J.B., 2011, 'Diffusion of green supply chain management: Examining perceived quality of green reverse logistics', The International Journal of Logistics 22(3), 373-389. https://doi.org/10.1108/ 09574091111181372

Hazen, B.T., Hall, D.J. \& Hanna, J.B., 2012, 'Reverse logistics disposition decisionmaking', International Journal of Physical Distribution \& Logistics Management 42(3), 244-274. https://doi.org/10.1108/09600031211225954

Hirsch, J. \& Harmanci, R, 2013, Food waste: The next revolution, viewed 05 June 2016 from http://modernfarmer.com/2013/09/next-food-revolution-youre-eating/

Ho, G.T.S., Choy, K.L., Lam, C.H.Y. \& Wong, D.W.C., 2012, 'Factors influencing implementation of reverse logistics: A survey among Hong-Kong businesses' Measuring Business Excellence 16(3), 29-46. https://doi.org/10.1108/ 13683041211257394 
Holweg, C., Teller, C. \& Kotzab, H., 2016, 'Unsaleable grocery products, their residual value and instore logistics', International Journal of Physical Distribution and Logistics Management 46(6), 634-658. https://doi.org/10.1108/IJPDLM-11-2014-0285

Hsu, C.C., Tan, K.C. \& Mohamad Zailani, S.H., 2016, 'Strategic orientations, sustainable supply chain initiatives, and reverse logistics: Empirical evidence from an emerging market', International Journal of Operations \& Production Management 36(1) 86-110. https://doi.org/10.1108/IJOPM-06-2014-0252

Huang, M., Song, M., Lee, L.H. \& Ching, W.K., 2013, 'Analysis for strategy of closedloop supply chain with dual recycling channel', International Journal of Production Economics 144(2), 510-520. https://doi.org/10.1016/j.ijpe.2013.04.002

Huscroft, J.R., Hazen, B.T., Hall, D.J., Skipper, J.B. \& Hanna, J.B., 2013, 'Reverse logistics: Past research, current management issues, and future directions', Internationa Journal of Logistics Management 24(3), 304-327. https://doi.org/10.1108/IJLM04-2012-0024

Kannan, D., Diabat, A., Alrefaei, M., Govindan, K. \& Yong, G., 2012, 'A carbon footprint based reverse logistics network design model', Resources, Conservation and Recycling 67, 75-79. https://doi.org/10.1016/j.resconrec.2012.03.005

Kapetanopoulou, P. \& Tagaras, G., 2011, 'Drivers and obstacles of product recovery activities in the Greek industry', International Journal of Operations \& Production Management 31(2), 148-166. https://doi.org/10.1108/01443571111104746

Khor, K.S. \& Udin, Z.M., 2013, 'Reverse logistics in Malaysia: Investigating the effect of green product design and resource commitment', Resources, Conservation and Recycling 81, 71-80. https://doi.org/10.1016/j.resconrec.2013.08.005

Kinobe, J.R., Gebresenbet, G., Niwagaba, C.B. \& Vinnerås, B., 2015, 'Reverse logistics system and recycling potential at a landfill: A case study from Kampala City', Waste Management 42, 82-92. https://doi.org/10.1016/j.wasman.2015.04.012

Lai, K. \& Wong, C.W.Y., 2012, 'Green logistics management and performance: Some empirical evidence from Chinese manufacturing exporters', Omega 40(3), 267-282. https://doi.org/10.1016/j.omega.2011.07.002

Lai, K., Wu, S.J. \& Wong, C.W.Y., 2013, 'Did reverse logistics practices hit the triple bottom line of Chinese manufacturers?', International Journal of Production Economics 146(1), 106-117. https://doi.org/10.1016/j.ijpe.2013.03.005

Lambert, S., Riopel, D. \& Abdul-Kader, W., 2011, 'A reverse logistics decisions conceptual framework', Computers and Industrial Engineering 61(3), 561-581. conceptual framework', Computers and
https://doi.org/10.1016/j.cie.2011.04.012

Lambert, V.A. \& Lambert, C.E., 2012, 'Qualitative descriptive research: An acceptable design', Pacific Rim International Journal of Nursing Research 16(4), 255-256.

Lamsali, H., 2013, 'Selection of return channels and recovery options for used products', Unpublished doctoral thesis, Loughborough University, Leicestershire, viewed 20 April 2016, from https://dspace.lboro.ac.uk/dspace-jspui/ bitstream/2134/13528/3/Thesis-2013-Lamsali.pdf

Larsen, S.B. \& Jacobsen, P., 2016, 'Revenue in reverse? An examination of reverse supply chain enabled revenue streams', International Journal of Physical Distribution \& Logistics Management 46(8), 783-804. https://doi.org/10.1108/ IJPDLM-03-2015-0054

Lee, C.K.M. \& Lam, J.S.L., 2012, 'Managing reverse logistics to enhance sustainability of industrial marketing', Industrial Marketing Management 41(4), 589-598. https://doi.org/10.1016/j.indmarman.2012.04.006

Madaan, J., Kumar, P. \& Chan, F.T.S., 2012, 'Decision and information interoperability for improving performance of product recovery systems', Decision Suppor Systems 53, 448-457. https://doi.org/10.1016/j.dss.2012.02.011

Mafakheri, F. \& Nasiri, F., 2013, 'Revenue sharing coordination in reverse logistics', Journal of Cleaner Production 59, 185-196. https://doi.org/10.1016/j. jclepro.2013.06.031

Manzini, R. \& Accorsi, R., 2013, 'The new conceptual framework for food supply chain assessment', Journal of Food Engineering 115(2), 251-263. https://doi.org/ 10.1016/j.jfoodeng.2012.10.026

Marchi, V.D., Maria, E.D. \& Micelli, S., 2013, 'Environmental strategies, upgrading and competitive advantage in global value chains', Business Strategy and the Environment 22(1), 62-72. https://doi.org/10.1002/bse.1738

McKinsey \& Company, 2011, Resource revolution: Meeting the world's energy material, food, and water needs, 25 April 2016, from http://www.mckinsey.com/ material, food, and water needs, 25 April 2016, from http://wwW.mckinsey.com/
business-functions/sustainability-and-resource-productivity/our-insights/ business-functions/s
resource-revolution

Min, H. \& Kim, I., 2012, 'Green supply chain research: Past, present, and future', Logistics Research 4, 39-47. https://doi.org/10.1007/s12159-012-0071-3

Mostert, W., Niemann, W. \& Kotzé, T., 2017, 'Supply chain integration in the product return process: A study of consumer electronics retailers', Acta Commercii 17(1), 1-18, a487. https://doi.org/10.4102/ac.v17i1.487

Myers, M.D., 2013, Qualitative research in business \& management, 2nd edn., Sage, Thousand Oaks, CA.

Neelankavil, J.P., 2015, International business research, 2nd edn., Routledge, New York.

Negi, S. \& Anand, N., 2014, Green and sustainable supply chain management practices - A study of Walmart 03 June 2016, from https://www.researchgate.net/profile/Saurav Negi/publication/278783443_Green_and_Sustainable_Supply_Chain_Management Practices-_A_Study_of_Wal-M̄art/links/55856b3808aebOcdaddd8eb2.pdf

Nikolaou, I.E., Evangelinos, K.I. \& Allan, S., 2013, 'A reverse logistics social responsibility evaluation framework based on the triple bottom line approach', Journal of Cleaner Production 56, 173-184. https://doi.org/10.1016/j.jclepro.2011.12.009

Öberseder, M., Schlegelmilch, B.B. \& Murphy, P.E., 2013, 'CSR practices and consumer perceptions', Journal of Business Research 66(10), 1839-1851. https://doi. org/10.1016/j.jbusres.2013.02.005
Peretti, U., Tatham, P., Wu, Y. \& Sgarbossa, F., 2015, 'Reverse logistics in humanitarian operations: Challenges and opportunities', Journal of Humanitarian Logistics and Supply Chain Management 5(2), 253-274. https://doi.org/10.1108/JHLSCM-07Supply Chain

Piplani, R. \& Saraswat, A., 2012, 'Robust optimisation approach to the design of service networks for reverse logistics', International Journal of Production Research 50(5), 1424-1437. https://doi.org/10.1080/00207543.2011.571942

Pishvaee, M.S., Razmi, J. \& Torabi, S.A., 2012, 'Robust possibilistic programming for socially responsible supply chain network design: A new approach', Fuzzy Sets and Systems 206, 1-20. https://doi.org/10.1016/j.fss.2012.04.010

Plano Clarke, V. \& Creswell, J.W., 2015, Understanding research: A consumer's guide, 2nd edn., Pearson, Upper Saddle River, NJ.

Pohlen, T.L. \& Farris, M.T., 1992, 'Reverse logistics in plastics recycling', International Journal of Physical Distribution \& Logistics Management 22(7), 35-47. https://doi. Journal of Physical Distribution \& Logis
org/10.1108/09600039210022051

Polit, D.F. \& Beck, C.T., 2012, Nursing research: Generating and assessing evidence for nursing practice, 9 th edn., Wolters Kluwer Health | Lippincott Williams \& Wilkins, Philadelphia, PA.

Prakash, C. \& Barua, M.K., 2015, 'Integration of AHP-TOPSIS method for prioritizing the solutions of reverse logistics adoption to overcome its barriers under fuzzy environment', Journal of Manufacturing Systems 37(3), 599-615. https://doi. org/10.1016/j.jmsy.2015.03.001

PWC, 2016, Prospects in the retail and consumer goods sector in ten sub-Saharan countries, viewed 03 June 2016, from http://www.pwc.co.za/en/assets/pdf/ retail-in-africa.pdf

Rahman, M., 2013, 'Green products: A study on young \& native Swedish consumers' purchase intentions of green products', Unpublished masters thesis, Umeå School
of Business \& Economics, Sweden, viewed 03 June 2016, from http://www.divaof Business \& Economics, Sweden, viewed 03 June 2016
portal.org/smash/get/diva2:668539/FULLTEXT01.pdf

Rahman, S. \& Subramanian, N., 2012, 'Factors for implementing end-of-life computer recycling operations in reverse supply chains', International Journal of Production recycling operations in reverse supply chains', International Journal of
Economics 140, 239-248. https://doi.org/10.1016/j.ijpe.2011.07.019

Ramírez, A.M., 2012, 'Product return and logistics knowledge: Influence on performance of the firm', Transportation Research 48, 1137-1151. https://doi. org/10.1016/j.tre.2012.06.001

Rogers, D.S., Melamed, B. \& Lembke, R.S., 2012, 'Modelling and analysis of reverse logistics', Journal of Business Logistics 33(2), 107-117. https://doi org/10.1111/j.0000-0000.2012.01043.x

Rossman, G.B. \& Rallis, S.F., 2011, Learning in the field: An introduction to qualitative research, 3rd edn., Sage, Thousand Oaks, CA.

Rubio, S., Chamorro, A. \& Miranda, F.J., 2008, 'Characteristics of the research on reverse logistics (1995-2005)', International Journal of Production Research 46(4), reverse logistics (1995-2005)', International Journal of Product
1099-1120. https://doi.org/10.1080/00207540600943977

Rutner, S.M., Aviles, M. \& Cox, S., 2012, 'Logistics evolution: A comparison of military and commercial logistics thought', The International Journal of Logistics Management 23(1), 96-118. https://doi.org/10.1108/09574091211226948

Saldaña, J., 2015, The coding manual for qualitative researchers, 2nd edn., Sage, London.

Sandelowski, M., 2000, 'Whatever happened to qualitative description?', Research in Nursing and Health 23, 334-340. https://doi.org/10.1002/1098-240X(200008) 23:4<334::AID-NUR9>3.0.CO;2-G

Sarkis, J., Zhu, Q. \& Lai, K., 2011, 'An organisational theocratic review of green supply chain management literature', International Journal of Production Economics 130, 1-15. https://doi.org/10.1016/j.ijpe.2010.11.010

Schulte, U.G., 2013, 'New business models for radical change in resource efficiency', Environmental Innovation and Societal Transitions 9, 43-47. https://doi. org/10.1016/j.eist.2013.09.006

Shaharudin, M.R., Zailani, S. \& Tan, K.C., 2014, 'Barriers to product returns and recovery management in a developing country: Investigation using multiple methods', Journal of Cleaner Production, 1-13, 16 July 2016, from https:// umexpert.um.edu.my/file/publication/00012642_103387.pdf

Sharma, S.K., Panda, B.N., Mahapatra, S.S. \& Sahu, S., 2011, 'Analysis of barriers for reverse logistics: An Indian perspective', International Journal of Modelling and Optimisation 1(2), 101-106. https://doi.org/10.7763/IJMO.2011.V1.18

Shenton, A.K., 2004, 'Strategies for ensuring trustworthiness in qualitative research projects', Education for Information 22, 63-75. https://doi.org/10.3233/EFI-200422201

Shi, X., Li, L.X., Yang, L., Li, Z. \& Choi, J.Y., 2012, 'Information flow in reverse logistics: And industrial information integration study', Information Technology And industrial information integration study', Information Te

Silva, D.A.L., Santos Renó, G.W., Sevegnani, G., Sevegnani, T.B. \& Serra Truzzi, O.M., 2013, 'Comparison of disposable packaging: A case study of reverse logistics in Brazil', Journal of Cleaner Production 47, 377-387. https://doi.org/10.1016/j. jclepro.2012.07.057

Sobral, M.C., Sousa Jabbour, A.B.L.D. \& Chiappetta Jabbour, C.J., 2013, 'Green benefits from adopting lean manufacturing: A case study from the automotive sector' Environmental Quality Management 22(3), 65-72. https://doi.org/10.1002/ tqem. 21336

Stoyanov, S., 2012, 'A theoretical model of reverse logistics network for end-of-life vehicles treatment in Bulgaria', Unpublished masters thesis, University of Aarhus, Bulgaria, viewed 02 June 2016, from http://pure.au.dk/portal-asb-student/ files/45645575/Master_Thesis_Svilen_Stoyanov.pdf

Subramanian, N., Gunasekaran, A., Abdulrahman, M. \& Liu, C., 2014, 'Factors for implementing end-of-life product reverse logistics in the Chinese manufacturing sector', International Journal of Sustainable Development \& World Ecology 21(3), 235-245. https://doi.org/10.1080/13504509.2014.906003 
Tan, A. \& Chanchaichujit, J., 2016, 'A decision making framework for reverse logistics network design', MIT Global Scale Network 1, 1-30.

Tejwani, Y. \& Sethi, A.S., 2012, 'Green business', A Journal of Economics and Management 1(7), 16-21.

Thamsatitdej, P., Jongpaiboon, M., Samaranayake, P. \& Laosirihongthong, T., 2015 Green supply chain management, triple bottom line, and organizational theory Prioritization with fuzzy AHP method', Industrial Engineering and Engineering Management 1, 1588-1592. https://doi.org/10.1109/ieem.2015.7385915

The Council of Supply Chain Management Professionals (CSCMP), 2013, Supply chain management terms and glossary, viewed 03 June 2016, from https://cscmp.org/ sites/default/files/user_uploads/resources/downloads/glossary-2013.pdf?utm source $=c s c m p s i t e \& u t m \_$medium $=$clicklinks\&utm_content=glossary\&utm campaign=GlossaryPDF

Turner, D.W., 2010, 'Qualitative interview design: A practical guide for novice investigators', The Qualitative Report 15(3), 754-760.

Vijayan, G., Kamarulzaman, N.H., Mohamed, Z.A. \& Abdullah, A.M., 2014 'Sustainability in food retail industry through reverse logistics', International Journal of Supply Chain Management 3(2), 11-23.

Vlachos, I.P., 2016, 'Reverse logistics capabilities and firm performance: The mediating role of business strategy', International Journal of Logistics Research and Applications 1, 1-19. https://doi.org/10.1080/13675567.2015.1115471

Wang, P., Zhou, G. \& Ren, J., 2010, 'Research on structure of reverse logistics network' Paper presented at 2010 International Conference of Logistics Engineering and Management (ICLEM 2010), Chengdu, China, 29-31 May, 1(5), 336-362.

World Bank, 2016, Population growth (annual \%), viewed 03 June 2016, from http:// data.worldbank.org/indicator/SP.POP.GROW
Ye, F., Zhao, X., Prahinski, C. \& Li, Y., 2013, 'The impact of institutional pressures, top managers' posture and reverse logistics on performance: Evidence from China', International Journal of Production Economics 143(1), 132-143. https://doi.org/ 10.1016/j.ijpe.2012.12.021

Yin, R.K., 2014, Case study research: Design and methods, 5th edn., Sage, Los Angeles, CA.

Yin, R.K., 2015, Qualitative research from start to finish, 2nd edn., Guilford, New York.

Zhang, X., Zhou, L. \& Leromonachou, P., 2013, 'The effect of uncertainty on economic performance of reverse logistic operation', Paper presented at 2013 International Conference on Advanced Logistics and Transport (ICALT), Sousse, Tunisia, 29-31 May, pp. 110-114, viewed 04 June 2016, from http://ieeexplore ieee.org/xpl/ articleDetals.jsp?tp=\&arnumber=6568444\&url=http\%3A\%2F\% 2Fieexplore. ieee.org\%2Fxpls\%2Fabs_all.jsp\%3Farnumber\%3D6568444

Zhao, X., Li, Y. \& Flynn, B.B., 2013, 'The financial impact of product recal announcements in China', International Journal of Production Economics 142(1), 115-123. https://doi.org/10.1016/j.ijpe.2012.10.018

Zhou, Q., Wen-hui, X.I.A., Dian-yan, J.I.A. \& Yu-ying, H.E., 2011, 'The remanufacturing reverse logistics management based on closed-loop supply chain management processes', Procedia Environmental Sciences 11, 351-354. https://doi. org/10.1016/j.proenv.2011.12.056

Zhu, Q. \& Geng, Y., 2013, 'Drivers and barriers of extended supply chain practices for energy saving and emission reduction among Chinese manufacturers', Journal of Cleaner Production 40, 6-12. https://doi.org/10.1016/j.jclepro.2010.09.017

Zikmund, W.G., Babin, B.J., Carr, J.C. \& Griffin, M., 2013, Business research methods, 9th edn., Cengage Learning, South-Western. 